\title{
COMPLEMENT FIXATION IN Q FEVER \\ III. SEROLOGICAL SURVEY OF HUMAN SERA IN JAPAN
}

\author{
KoUichi TAKANO*, MASAMI KITAOKA AND AKIRA SHISHIDO
}

Viral and Rickettsial Division, The National Institute

of Health, Tokyo, Japan

(Received: July 19th, 1954)

As etiological investigation in $Q$ fever improved, its geographical distribution has become clear, and the presence of this disease has been proved almost all over the world. In Japan also, since 1951, when it was required to examine camels imported on $Q$ fever(1), many investigators in the field of rickettsiology have got interested in this disease, and so, Fukuzumi and Saito(2), Matsubayashi(3), Kitaoka $(4,5,6)$ and many other workers published reviews on $Q$ fever in succession. On the other hand, experimental studies are being carried out in many laboratories. The crucial proof of existence of $Q$ fever in Japan is of course the isolation of Coxiella burnetii, and there has not been yet reported its occurrence or prevalence but laboratory infection by Tazaka and Tameda(7) and by Kitaoka ${ }^{(8)}$ in our own laboratory, then we will be able to only guess it by serological survey. Such a survey, however, can not be significant until it is done widely in both human beings and domestic animals, compared with isolation of causative agent in infected districts, as Irons, Murphy and Wolfe reported(9) in the United States of America.

The symptoms of $Q$ fever are so complicated that it can hardly be differenciated from other infectious diseases as described by Feinstein, Yensen and Marks (10). Especially in Japan, where its existence can not be decided at the present moment, $Q$ fever may possibly be included in atypical pneumonia or other acute respiratory diseases. As reported by Lennette, Dean, Akinanti, Clark, Winn and Holmes (11), Lennette and Welsh ${ }^{(12)}$ and Clark, Lennette and Romer(13), Coxiella burnetii, however, is prevailable among so common domestic animals and its resistance is so much great that this agent will probably give rise to a widespread infection according to transfer of live-stock.

At any rate, it has become a subject of discussion, unexpectedly as mentioned previously ${ }^{(1)}$, whether or not $Q$ fever exists in Japan. Survey should be carried cut as widely as possible in both human beings and animals. In response to the survey of live-stock started by the Animal Hygiene Experimental Laboratory, Agriculture and Forest Ministry, we collected serum samples of people who had

* Present address: Pathology Division, The National Institute of Health, Tokyo, Japan 
chance to come in contact with live-stock throughout the country, and undertook the serological test on those samples.

\section{Material AND Method}

In March, 1952, an official document concerning the collection of serum samples was issued from the Welfare Ministry to the authorities of every prefecture in Japan, and according to this request, serum samples were taken from people who were working in slaughter-houses and live-stock health centers and as veterinarians and meat dealers, those had all more or less chance to touch animals directly, and sent to the National Institute of Health for the purpose of being tested in our laboratory. It was requested to offer a paper, besides serum samples, with descriptions of the person to be bled on frequency or grade in touching animals, on anamnesis especially including pneumonia, influenza, typhus group or any other similar disease and on vaccination against typhus.

We used complement-fixation test as method of serological test. Procedures and technics of the test followed those directed by WHO which had been modified partly according to our own experimental results(14). Antigens were prepared from both Nine Mile and Henzerling strains of $C$. burnetii in our laboratory, and each serum was tested after being inactivated by heating at $56^{\circ} \mathrm{C}$ for 30 minutes and serially two-fold diluted starting at 1:8, and then decided the highest significant dilution as its antibody titer. The details of preparation of antigens and reading the results of test were described in (1) and (14). Besides Q fever antigens, we used typhus group antigens from both Rickettsia prowazekii and $R$. typhi as control.

\section{RESULT}

During the period from March, 1952 to March, 1953, 954 samples of sera were sent to our laboratory from 17 prefectures over Japan. General results of complement-fixation test done with those sera were shown in Table 1. Figures in Table 1 represent the numbers of samples, including some cases in which same persons were bled twice, if it was needed when some sera showed once positive result or were in bad condition to get clear result.

The significant complement-fixing titer for the detection of $\mathrm{Q}$ fever decided by WHO is 1:32 or higher for human sera and 1:16 or higher for animal sera(15). It is questionable, however, whether such standard can be used as it is in our survey undertaken for the first time in Japan. We just decided, therefore, that a serum showing the titer higher than 1:8 at least either of $\mathrm{Q}$ fever antigens was positive and one showing no significant complement-fixation at 1:8 dilution was negative. Among sera sent from Kanagawa, Kumamoto, Okayama Prefectures, there were some showing positive in the meaning as mentioned above, and sera from other prefectures were all negative. Meanwhile, there were much more sera than expected, namely $16.1 \%$, of which the results were unable to be read due to high 
Table 1. Summarized Result of Complement-fixation Test to $Q$ Fever on Human Sera in Japan

\begin{tabular}{|c|c|c|c|c|c|c|}
\hline \multirow{2}{*}{$\begin{array}{l}\text { Name of } \\
\text { Prefecture }\end{array}$} & \multirow{2}{*}{$\begin{array}{l}\text { No. of } \\
\text { Samples } \\
\text { Sent }\end{array}$} & \multirow{2}{*}{$\begin{array}{l}\text { No. of } \\
\text { Samples } \\
\text { Lost }\end{array}$} & \multirow{2}{*}{$\begin{array}{c}\text { No. of } \\
\text { Samples } \\
\text { Tested }\end{array}$} & \multicolumn{3}{|c|}{ Result } \\
\hline & & & & $\begin{array}{l}\text { Q Fever } \\
\text { Positive }\end{array}$ & $\begin{array}{l}\text { Q Fever } \\
\text { Negative }\end{array}$ & $\begin{array}{l}\text { Undeter- } \\
\text { mined }{ }^{* *}\end{array}$ \\
\hline Hokkaido & 32 & 0 & 32 & 0 & $32(0) *$ & 0 \\
\hline Yamagata & 37 & 1 & 36 & 0 & $32(7)$ & 4 \\
\hline Fukushima & 8 & 0 & 8 & 0 & $5(0)$ & 3 \\
\hline Ibaragi & 126 & 0 & 126 & 0 & $109(5)$ & 17 \\
\hline Gumma & 110 & 1 & 109 & 0 & $59(4)$ & 50 \\
\hline Saitama & 3 & 0 & 3 & 0 & $3(1)$ & 0 \\
\hline Tokyo & 2 & 0 & 2 & 0 & $2(0)$ & 0 \\
\hline Kanagawa & 144 & 1 & 143 & $8(4)^{*}$ & $129(17)$ & 6 \\
\hline Niigata & 38 & 2 & 36 & 0 & $36(\cdot 0)$ & 0 \\
\hline Toyama & 8 & 0 & 8 & 0 & $8(0)$ & 0 \\
\hline Ishikawa & 27 & 0 & 27 & 0 & $19(1)$ & 8 \\
\hline Yamanashi & 29 & 0 & 29 & 0 & $29(0)$ & 0 \\
\hline Okayama & 35 & 0 & 35 & $2(1)$ & $29(0)$ & 4 \\
\hline Kagawa & 34 & 0 & 34 & 0 & $34(12)$ & 0 \\
\hline Kumamoto & 136 & 2 & 134 & $29(14)$ & $74(13)$ & 31 \\
\hline Oita & 11 & 0 & 11 & 0 & $6(2)$ & 5 \\
\hline Miyazaki & 174 & 12 & 162 & 0 & $136(34)$ & 26 \\
\hline Total & 954 & 19 & 935 & $39(19)$ & $742(96)$ & 154 \\
\hline
\end{tabular}

degree of hemolysis, contamination, turbidness or anticomplementary reaction. As for such unsuitable sera, bleeding was repeatedly demanded if possible.

Schubert, Stanford and Tiffany ${ }^{(16)}$ and Kitaoka and Takano(17) reported the fact on complement-fixation test in rickettsial diseases, that one serum showing a certain titer to a certain antigen could react positively with other sort of antigens when the test technic was alternated with another more sensitive one. Though our technic had already been examined satisfactorily on its sensitivity and specificity in the previous paper(1), we tested all of sera as well to antigens of typhus group as to $\mathrm{Q}$ fever antigens simultaneously for making sure of this point. As result, almost half of Q-positive sera reacted positively with the others. This fact will be discussed afterwards.

Q fever positive sera were repeatedly tested under the same condition in order to ascertain the result, omitting technical failures. About positive cases, blood was taken once again from the same person after a certain period, usually about one month, to be examined if there would occur any change in serum antibody titer. In 2 of 3 prefectures mentioned above, samples could be possibly 
taken not only from the persons in question but also from their families, neighbors and, furthermore, from the domestic animals they might touch. Results will be described in detail as follows:

Survey in Kumamoto Prefecture: Among 80 samples of sera sent from Kumamoto Prefecture in April, 1952, 16 showed titers 1:8 or higher to Henzerling antigen, when we were obliged to use only Henzerling, because Nine Mile antigen was occasionally short. One of the authors went at once to the prefecture and took the blood specimens from live-stock dealers, including the persons in question, their families and neighbors and, furthermore, from domestic animals kept in the prefecture, as in wide range as possible, and complement-fixation test was done with these sera in our laboratory.

Bleeding could be done in 10 of 16 persons who had shown previously positive results, and these sera were examined with both Nine Mile and Henzerling antigens in the second test, resulting that all 10 sera but one, which showed anticomplementary reaction, were positive with equal titers to both antigens, 2 of which had less titer in the second test than in the first, 7 remainders reacted equally in both tests, and besides, there was found another case, of which the first sample had been negative to Henzerling antigen, the second one reacting positively only with Nine Mile. Table 2 shows the result in detail.

Table 2. Q Fever Positive Cases in Kumamoto Prefecture

\begin{tabular}{|c|c|c|c|c|}
\hline \multirow{2}{*}{\multicolumn{2}{|c|}{$\underbrace{\text { Q Fever Titer }}_{\begin{array}{l}\text { Name, } \\
\text { Sex \& Age }\end{array}}$}} & \multirow{2}{*}{$\begin{array}{c}\begin{array}{c}\text { First Test } \\
\text { (April, 1952) }\end{array} \\
\text { Henzerling }\end{array}$} & \multicolumn{2}{|c|}{$\begin{array}{l}\text { Second Test } \\
\text { (June, 1952) }\end{array}$} \\
\hline & & & Nine Mile & Henzerling \\
\hline 1. & (m) 23 & $1: 8$ & \multirow{5}{*}{ 1: 8} & \multirow{5}{*}{ 1: 8} \\
\hline 2. & (m) 22 & $1: 16$ & & \\
\hline 3. & (m) 23 & $1: 16$ & & \\
\hline 4. & (m) 24 & $1: 16$ & & \\
\hline 5. & (f) 33 & $1: 16$ & & \\
\hline 6. & (m) 26 & $1: 8$ & 1: 8 & $1: 8$ \\
\hline 7. & (m) 34 & $1: 16$ & $1: 16$ & $1: 16$ \\
\hline 8. & (m) 19 & 1: 8 & $1: 8$ & 1: 8 \\
\hline 9. & (m) 44 & $1: 32$ & $1: 32$ & 1:32 \\
\hline 10. & (m) 22 & $1: 16$ & $1: 16$ & $1: 16$ \\
\hline 11. & (m) $5 \delta$ & $1: 16$ & $1: 16$ & $1: 16$ \\
\hline 12. & (m) 31 & $1: 32$ & $1: 16$ & $1: 16$ \\
\hline 13. & (m) 52 & $1: 16$ & \multirow[t]{2}{*}{$1: 16$} & \multirow[t]{2}{*}{$1: 16$} \\
\hline 14. & (m) 38 & $1: 32$ & & \\
\hline 15. & (m) 28 & $1: 32$ & \multicolumn{2}{|c|}{ anticomplementary } \\
\hline 16. & (m) 42 & $1: 8$ & \multirow[b]{2}{*}{$1: 8$} & \multirow[b]{2}{*}{$<1: 8$} \\
\hline 17. & (m) 23 & $<1: 8$ & & \\
\hline
\end{tabular}

Serum samples of the families and neighbors of the persons who had shown positive results in the previous test were all negative in the second, and the 
Table 3. Survey of Human Sera in Kumamoto Prefecture

\begin{tabular}{c|c|c|c|c}
\hline Subject & No. Tested & $\begin{array}{c}\text { Q-positive } \\
(\geqq 1: 8)\end{array}$ & $\begin{array}{c}\text { Q-negative } \\
(<1: 8)\end{array}$ & $\begin{array}{c}\text { Undeter- } \\
\text { mined }\end{array}$ \\
\hline Live-stock & 80 & $17\left\{\begin{array}{l}5(1: 8) \\
8(1: 16) \\
4(1: 32)\end{array}\right.$ & 44 & 19 \\
Dealers & & 0 & & \\
Families & 18 & 0 & 17 & 1 \\
Neighbors & 9 & 0 & 9 & 0 \\
Total & 107 & 17 & 70 & 20
\end{tabular}

results of serological survey of human sera in the prefecture could be summarized, as shown in Table 3, as follows: 1) Seventeen of 107 persons were $Q$ fever positive, 2) They had all had the chance to touch domestic animals directly, 3) Five of them showed 1:8 titer, $81: 16$ and $41: 32,4)$ The localities of their working places scattered through the prefecture and there was not any area the positive cases focused in, 5) Two of 4 who showed titer 1:32 were working at livestock health center, one meat examiner and the last meat dealer; 2 of them had experienced in past influenza and acute pneumonia, respectively. As for survey of animals, among totally 80 of cattle, goats, horses and pigs, one cattle and 3 goats showed positive result, titer being 1:8 to only Nine Mile in all cases.

Survey in Kanagawa Prefecture: The survey in Kanagawa Prefecture was carried out in several separate series started in July, 1952 and ended in September, 1952. Sera of 5 persons among 137 reacted positively, and further test was done after bleeding again these persons. The result, as shown in Table 4, was that 3 of 5 mentioned above showed almost same titers as those in the former

Table 4. Q Fever Positive Cases in Kanagawa Prefecture

\begin{tabular}{|c|c|c|c|c|c|}
\hline \multirow{2}{*}{\multicolumn{2}{|c|}{$\begin{array}{l}\text { Q Fever Titer } \\
\text { Name, } \\
\text { Sex \& Age }\end{array}$}} & \multicolumn{2}{|c|}{ First Test } & \multicolumn{2}{|c|}{ Second Test } \\
\hline & & Nine Mile & Henzerling & Nine Mile & Henzerling \\
\hline 1. & (m) 39 & 1: 16 & $<1: 8$ & $1: 16$ & $<1: 8$ \\
\hline 2. & (m) 45 & $1: 8$ & $<1: 8$ & $<1: 8$ & $<1: 8$ \\
\hline 3. & (m) 42 & $1: 8$ & $1: 8$ & $<1: 8$ & $<1: 8$ \\
\hline 4. & (m) 22 & 1: 16 & $<1: 8$ & 1: 16 & $<1: 8$ \\
\hline 5. & (m) 51 & $\geqq 1: 128$ & $<1: 8$ & $1: 256$ & $1: 8$ \\
\hline
\end{tabular}

examination and 2 others were determined as negative in the second test, though they showed inclination to react with $\mathrm{Q}$ fever antigens even to a slight extent.

There was only one case which showed titer higher than 1:32. The serum of this person did not get the end-point at dilution of 1:128 in the primary test, in which we could not repeat the test because of short in volume of serum sample and were obliged to determine the titer of this serum as $\geqq 1: 128$. The second sample of the same person, however, showed the end-point in titer as 1:256 
when it was tested about one month later, then it can be thought that there should not have been so much difference between formerly got titer and the latter.

This person was conducting a ranch, and so, he usually touched many animals. In occasion at the beginning of 1951, while he was keeping goats imported from England, one of them showed influenza- or common cold-like symptoms, and it was sent to another pasture after recovered. A little later, the person himself had an attack of fever without any known cause, but got better without consulting a physician.

We examined, in this connection, the sera of 2 of his families, who worked at the same place, twice each, but the results were all negative.

Survey in Okayama Prefecture: Two of 35 sera reacted with Nine Mile antigen, titers being $1: 8$ and $1: 16$, respectively. It was requested to bleed again those 2 cases, but was not fulfilled.

\section{Discussion}

When the serological survey of $\mathrm{Q}$ fever is carried out, it matters what kind of method should be used. Various methods or technics have been studied by Bengtson(18), Siegert, Peter, Simrock and Schweinsberg(19), Babudieri and Secchi(20), Victor, Raymond, Valliant, Wagner and Pollack(21) and many other workers, and Robbins, Rustigian, Snyder and Smaddel(22), Topping, Shepard and Huebner ${ }^{(23)}$ and Siegert, Simrock and Schweinsberg(24) studied on occurrence and duration of the antibody, using comparable several methods, but their conclusions did not always agreed with each other.

We used complement-fixation test which is most prevailing at the present as serological survey method for the detection of $Q$ fever, investigating the procedure and technic of test(1) and preparation of antigen, and comparing this test with agglutination test(14), and undertook these series of survey.

As $Q$ fever is originally an infectious disease for both human beings and domestic animals, especially related with cattle, such a survey should be done first with animals and then with human beings. As reported by Omori, Harada and Kuroda(25), the result of complement-fixation test carried out on sera of domestic animals through Japan was that 3 of 1,350 cattle, 2 of 17 goats and 3 of 5 camels were decided positive for $Q$ fever, its existence in Japan being suspected, and the fact that reaction with Nine Mile and Henzerling antigens depended upon the species of animals was in accord with our own assumption(14).

It is regrettable that there were unexpectedly many samples which were in bad state, interfering reading the rsults. The probable reason was carelessness in bleeding, preservation and sending of samples.

At any rate, it is difficult to easily conclude that $Q$ fever is or has ever been existing in Japan on the basis of this survey. It is not need to say the crucial proof is isolation of $C$. burnetii. This causative agent, however, has so much great resistance and infectivity as shown by many research workers that special 
laboratory equipped satisfactorily to avoid undesirable contamination should be established before this agent will be dealt in several aspects of investigation. In this point of view, we attempted this time only serological survey by means of complement-fixation test.

There were 24 persons in all whose sera reacted with $\mathrm{Q}$ fever antigens in the titer of $1: 8$ or higher, 17, 5 and 2 of them being from Kumamoto, Kanagawa and Okayama Prefectures, respectively. Among them, 5 were positive according to WHO's standard, namely 1:32 or higher in titer, of which 4 from Kumamoto and 1 from Kanagawa Prefectures, respectively. The titers of 4 from Kumamoto were all 1:32, and 2 of them had anamnesis of acute respiratory disease. One from Kanagawa showed titer of 1:256 and was suspectable to have experienced infection of $\mathrm{Q}$ fever, from the point of view on his circumstances.

Almost half of sera, which showed titer of 1:8 or higher to $Q$ fever, reacted with typhus group antigens, too. As the overlapping phenomenon in serological reaction between $Q$ fever and typhus group has not been observed yet, it can be supposed due to the fact that a burst of typhus epidemic occurred throughout Japan immediately after war and from that time on nation-wide vaccination against typhus was repeated several times. The significant minimum titer in human sera, 1:32, decided by WHO must have so far been standardized on the basis of experimental data in past, and it is important fact that some sera reacted with $\mathrm{Q}$ fever even to a little extent in Japan where such investigation was carried out for the first time. Among positive sera, some reacted almost equally with both Nine Mile and Henzerling antigens, others with only Nine Mile, and so, to speak generally, Nine Mile may be more suitable to be used as antigen in such a serological survey.

Though further studies should be done on geographical distribution of positive cases, number of samples and prefectures investigated being far from satisfactable quantity, it seems to be permitted to assume, from these results mentioned above, that $\mathrm{Q}$ fever may exist in Japan.

\section{SUMMARY}

For about one year period from March, 1952 to March, 1953, serum samples were taken from persons had chance to touch many sorts of live-stock throughout Japan and complement-fixation test was carried out with these sera, using $\mathrm{Q}$ fever antigens. The results are summarized as follows:

1) Among 954 serum samples sent from 17 prefectures, 39 of 24 persons showed titer of 1:8 or higher, 17 of them being from Kumamoto Prefecture, 5 from Kanagawa and 2 from Okayama, and the number of persons who showed titer higher than 1:32 was totally 5, 4 in Kumamoto and 1 in Kanagawa.

2) Two of 4 positive persons in Kumamoto mentioned above had anamnesis of acute respiratory disease, and 1 in Kanagawa experienced a feverish disease 
after goat imported, which had been kept by him, showed common cold-like symptoms, being suspectable to have been infected with $Q$ fever.

3) As mentioned above, even though from only serological point of view, it can be assumed that $Q$ fever exists in Japan. Investigation of the causative agent, however, which will help certifying this assumption, is still remained.

The authors should appreciate the authorities of every prefecture for their kind help in taking and sending serum samples and in investigation of the subjects.

\section{REFERENCES}

(1) Kitaoka, M. and Takano, K.: Complement fixation in Q fever. I. Comparative evaluation of several technics. Jap. J. Med. Sci. and Biol., 5, 493-500, 1952.

( 2 ) Fukuzumi, S. and Saito, Y.: On Q fever. Tokyo Med. J., 69, 179-185, 1952 (in Japanese).

( 3 ) Matsubayashi, S.: On Q fever. Jap. Med. J., No. 1454, 782-784, 1952 (in Japanese).

(4) Kitaoka, M.: On Q fever. Rinsho, 5, 423-427, 1952 (in Japanese).

(5) Kitaoka, M.: On the Rickettsioses never found in Japan. Rinsho, 5, 644-649, 1952 (in Japanese).

(6) Kitaoka, M.: Q fever in Japan. Jap. J. Bact., 8, 156-162, 1953 (in Japanese).

( 7 ) Tazaka, S. and Tameda, K.: On Q fever. Jap. Med. J., No. 1478, 2809-2814, 1952 (in Japanese).

(8) Kitaoka, M.: Q fever. I. Koshueisei, 15, 2-10, 1954 (in Japanese).

( 9 ) Irons, J. V., Murphy, J. N. and Wolfe, D. M.: Q fever in the U. S. III. Serologic observations etc. J. A. M. A., 133, 819-820, 1947.

(10) Feinstein, M., Yensen, R. and Marks, J. L.: Epidemics of $Q$ fever among troops returning from Italy in spring of 1945. I. Clinical aspects of epidemic at Camp Patrick Henry, Virginia. Am. J. Hyg., 44, 72-87, 1946.

(11) Lennette, E. H., Dean, B. H., Akinanti, F. R., Clark, W. H., Winn, J. F. and Holmes, M. A.: Q fever in California. V. Serologic survey of sheep, goats and cattle in three epidemiologic categories, from several geographic areas. Am. J. Hyg., 54, 1-14, 1951.

(12) Lennette, E. H. and Welsh, H. H.: Q fever in California. X. Recovery of Coxiella burneti from the air of premises harboring infected goats. Am. J. Hgy., 54, 44-49, 1951.

(13) Clark, W. H., Lennette, E. H. and Romer, M. S.: Q fever in California. IX. An outbreak aboard a ship transporting goats. Am. J. Hyg., 54, 35-43, 1951.

(14) Takano, K. and Kitaoka, M.: Complement fixation in $Q$ fever. II. Preparation of antigen and its antigenicity. Jap. J. Med. Sci. and Biol. 6, 415-424, 1953.

(15) Kaplan, M. M.: Survey methods for the detection of $Q$ fever. Division of Epidemiological Services, World Health Organization, Geneva.

(16) Schubert, J. H., Stanford, S. M. and Tiffany, E. J.: Comparative evaluation of several complement fixation techniques for laboratory diagnosis of the ricketsioses. J. Lab. and Clin. Med., 37, 388-393, 1951.

(17) Kitaoka, M. and Takano, K.: Comparative study on complement fixation technics in rickettsial diseases. Jap. J. Med. Sci. and Biol., 6, 119-129, 1953.

(18) Bengtson, I. A.: Complement fixation in "Q" fever. Proc. Soc. Exper. Biol, and Med., 46, 665-668, 1941. 
(19) Siegert, R., Peter, H., Simrock, W. and Schweinsberg, H.: Q-Fieber-Studien. I. Mitt. Herstellung und Auswertung diagnostischer Antigene. Zbl. f. Bakt., I Orig., 157, 309-325, 1951.

(20) Babudieri, B. and Secchi, P.: La reazione di agglutinazione nella serodiagnosi dell'infezione do Coxiella burneti. Estrat. Rendi. Del'istit. Super. Sani., 15, 584-608, 1952.

(21) Victor, J., Raymond, R., Valliant, J., Wagner, J. C. and Pollack, A. D.: Studies on opsonins in Q fever. J. Exp. Med., 95, 61-70, 1952.

(22) Robbins, F. C., Rustigian, R., Snyder, M. J. and Smaddel, J. E.: Q fever in the Mediterranean Area: Report of its occurrence in Allied Troops. III. The etiological agent. Am. J. Hyg., 44, 51-63, 1946.

(23) Topping, N. H., Shepard, C. C. and Huebner, R. J.: Q fever. An immunological comparison of strains. Am. J. Hyg., 44, 173-182, 1946.

(24) Siegert, R., Simrock, W. and Schweinsberg, H.: Q-Fieber-Studien. 2. Mitt. Zeitliche Entwicklung und Verweildauer komplement-bindender und agglutinierender Antikörper ber unbehandelten und hehandelten Q-Fieberpatienten. Zbl. f. Bakt., I Orig., 159, 159-169, 1953.

(25) Omori, T., Harada, K. and Kuroda, S.: Survey of $Q$ fever. I. The result of complement-fixation test on sera of cattle and others in Japan. Jap. J. Bact., 7, 404-405, 1952 (in Japanese). 